\title{
Ética y medio ambiente. La descomposición y recomposición de la razón práctica
}

\author{
JOSÉ M. ${ }^{a}$ GARCÍA GÓMEZ-HERAS \\ Universidad de Salamanca
}

\begin{abstract}
Resumen. Todos observamos con inquietud un hecho incuestionable: el deterioro medioambiental de nuestro planeta «tierra». Muchos, además, reconocemos que la acción del hombre tiene mucho que ver con tal deterioro. Surge, por tanto, una pregunta ineludible: ¿Somos responsables de la crisis ecológica? Ésta, en ese caso, nos emplazaría ante un grave problema moral. En el pasado, la filosofía construyó los diferentes modelos de racionalidad práctica en función de los problemas a los que la humanidad tuvo que enfrentarse en un determinado momento de su historia. De ahí que, tras los múltiples intentos de reconstruir aquella racionalidad, parezca pertinente hoy en día reivindicar una reconstrucción de la ética priorizando en ella el problema de la dimensión moral de la acción humana sobre la naturaleza. Éste es el problema que aborda el presente ensayo.
\end{abstract}

\begin{abstract}
Nowadays, everybody is worried about an in questionable fact, that is, the environmental deterioration of our planet earth. In addition, many people are able to recognize that human action has a lot to do with that deterioration. Therefore, the following question seems unavoidable: are human beings responsible for the ecological crisis? If the answer to the question is affirmative, then, we would have to face a very important problem. In the past, philosophy built different models of practical rationality according to the problems which mankind had to face at each moment of their history. So, after multiple attempts to reconstruct «Practical rationality», it seems relevant to suggest a reconstruction of ethics in the present. This reconstruction should give priority to the case of the moral dimension of human action on nature. This essays addresses that case.
\end{abstract}

Durante su regreso a Ítaca, Ulises se entretuvo largo tiempo con la ninfa Calipso, olvidándose de su tierra. Sólo con el apoyo de Atenea recuperó la nostalgia de la patria e inició al retorno. Homero nos narró en la Odisea las aventuras y desventuras de aquel viaje, lleno de peligros, astucias, triunfos y tragedias. No es nuestra situación la de Ulises. Pero a semejanza de él, también la razón práctica, en lo que concierne a las relaciones entre el hombre y la naturaleza, ha escenificado su propia odisea, hasta redescubrir sus orígenes y raíces. Rastrear ese peregrinar al encuentro consigo misma nos permite descubrir las posadas y estancias de la razón práctica en la metafísica, en 
la religión, en la subjetividad, en la conciencia, en la sociedad... hasta llegar a una, no la única, en donde hoy en día busca albergue: la naturaleza.

\section{Un cliché convertido en tópico}

Ha hecho fortuna en el ensayo medioambiental un binomio harto simplista para designar dos tipos de ética: antropocentrismo y fisiocentrismo. Ambos se inspirarían en convicciones opuestas y aportarían sendos encuadres, potencialmente conflictivos para plantear y solucionar problemas en las relaciones entre el hombre y la naturaleza. Uno, el modelo antropocéntrico, se mantendría dentro de los límites convencionales de la ética tradicional, en la que ya desde Sócrates el protagonismo lo detenta la persona humana, cuyas decisiones y acciones respecto a la naturaleza son racionales en cuanto que reportan al hombre utilidad, placer, felicidad, bienestar o provecho. Se trataría, por tanto, de una tipo de racionalidad práctica, en la que él interés del hombre prevalece sobre el de la naturaleza. Animales, plantas, aguas, aires y todo lo que entendemos por entorno, son vistos como materiales útiles para el hombre. La naturaleza aparece como un medio y el hombre como un fin, al que aquélla se ordena. En tal perspectiva el hombre actúa como encargado y administrador de una naturaleza que le pertenece. Pero ésta no posee en sí misma valores y dignidad de modo que se haga acreedora de respeto y aprecio. Otro, el modelo fisiocéntrico, cree ineludible una ruptura con el modelo anterior, vigente en la tradición moral occidental, dada su incapacidad para hacerse cargo de los problemas medioambientales. Opta, en cambio, por una naturaleza entendida como un fin y un valor en sí misma, los cuales, por ser tales, fundamentan un tipo diferente de racionalidad, de deber y de responsabilidad. La precedente alternativa se convierte para muchos en criterio básico para distinguir qué tipos de compromisos se adquieren respecto a la naturaleza y que fundamentación se propone para la construcción del discurso moral 1.

Muchos reiteran insistentemente que el ethos tradicional es producto del antropocentrismo ${ }^{2}$. Es un cliché convertido en tópico. Pero la aserción no carece de avales. Sócrates, Platón, Aristóteles, Agustín de Hipona, Tomás de Aquino, I. Kant, M. Scheler... lo testimonian. Las estructuras básicas de los modelos convencionales de ética: valores, normas, deberes, imperativos, responsabilidades... se cimentan sobre un conjunto de cualidades del hombre. Aquellas que le confieren el estatuto de persona, tales como la capaci-

${ }^{1}$ Cf. D. von d. Pfordten, Die Struktur einer Oekologischen Ethik jenseits menschlicher Interessen en Oekologische Ethik. Zur Rechtfertigung menschlichen Verhaltens gegenüber der Natur, Munich, 1994, pp. 10 ss.

${ }^{2}$ Cf. J. M. ${ }^{\mathrm{a}} \mathrm{G}^{\mathrm{a}}{ }^{\mathrm{G}}$ Gómez-Heras (coord.), Ética del medio ambiente. Problema, Perspectivas, Historia, Madrid, 1997, pp. 30 ss. 
dad de saber y razonar (Sócrates), de poseer dignidad de origen divino (cristianismo), de decidir autónomamente en libertad (Kant), de ser susceptible de placer o desplacer (hedonismo), de liberarse del dolor y gozar de bienestar (utilitarismo), etc., o le reconocen capacidad para entablar relaciones con sus semejantes y organizar la convivencia con ellos de modo justo y pacifico. Con el correr del tiempo el antropocentrismo habría derivado hacia patologías del egoísmo humano a veces individualmente practicado y a veces socialmente promovido. De ahí que se le haya etiquetado como egoísmo de la especie humana frente a los seres no humanos. Al antropocentrismo se atribuyen consecuencias fatales para una ética de la naturaleza: desarraigo del hombre de su medio, negación de valores intrínsecos a la naturaleza, no reconocimiento de derechos a los no humanos, consumismo utilitario, pulsiones autodestructivas...

La teología de la naturaleza desarrollada por el judeocristianismo, con las ideas de creación, conservación y providencia como categorías centrales, poseía virtualidades más que suficientes para fundamentar un orden objetivo de valores sobre el que legitimar un sistema de conducta del hombre respecto a la naturaleza. Tales planteamientos permitieron articular una interpretación teleológica del medio ambiente, apta para fundamentar una axiología objetiva y desde la misma una fundamentación de obligaciones morales. En este sector, como en otros muchos, la cosmología clásica griega proporcionó, previa reconversión religiosa de su sentido, abundantes materiales a la imagen judeocristiana del mundo. Los intentos de conciliación a lo largo del Medioevo de la fe y de la razón, de la filosofía y de la teología, mostraron cuán profundamente había planteado este problema la gran escolática y cuán problemática era una respuesta impuesta por una metafísica esencialista de impronta aristotélica. Anclada, pues, en la creencia de un ordo naturae de origen divino, la ética cristiana desarrolló desde antiguo una idea de naturaleza en la que ésta no solamente poseía una peculiar dignidad derivada de su origen divino, sino que implicaba estructuras que la convertían en instancia legisladora ${ }^{3}$. La famosa lex naturae, base del iusnaturalismo, así lo mostraba. Desde tal posición la tradición cristiana se mostró recelosa ante las manipulaciones tecnológicas de la naturaleza a causa de los riesgos que las mismas implicaban de violentar los comportamientos y leyes naturales. Éstas se fundamentarían en el modo de ser o esencia de las cosas y, en cuanto tales, impondrían obligación a las conciencias. La naturaleza reproduce el ordo naturae querido por Dios y toda violación del mismo implica una transgresión de la ley divina. Bien es verdad que en aquel ordo naturae al hombre le corresponde, en tanto imago Dei, un puesto privilegiado, que

${ }^{3}$ Ateniéndose al dicho del Genesis, 1, 31: «Y vio Dios que era muy bueno cuanto había creado», S. Agustín puede escribir que al ser Dios «auctor et conditor» de la naturaleza, «omnis natura in quantum natura est, bona est». Cf. De Genesi ad Litt., 2, 15, 30, PL. 34, 276; De civitate Dei, 12, 25, PL. 41, 374; De libero arbitrio, 3, 13, 36 en PL. 41, 722 respectivamente. 
podría derivar en ambición de dominio y explotación del mundo. En todo caso, más que hablar de antropocentrismo cristiano, sería más apropiado hablar de teocentrismo naturalista, dado el papel que la tradición cristiana asignó a la lex divina y a su participación, la lex naturae, en la dinámica del cosmos 4 .

Pero la Modernidad, a partir del Renacimiento, asienta sus reales en el sujeto. También la moralidad. Cualquier mundo dado con antelación al hombre se tamiza a través de la autoconciencia y los valores son algo que el hombre crea e interpreta desde la propia subjetividad 5. El sujeto autónomo moderno despliega sus virtualidades prácticas por dos caminos que desembocan en las sociedades contemporáneas: el de la libertad, que conduce a las democracias, y el de la ciencia, que posibilita la civilización técnico-industrial. En ambos casos, sin embargo, la suerte que corre la razón práctica es muy diferente. Por el camino de la libertad, como el potente sistema kantiano testimonia, la ética alcanza la cima del proyecto moral burgués, ilustrado, racionalista e individualista. Por el otro camino, el de la ciencia, mientras el sujeto concentra todo su poder creador en el conocimiento teórico, en el terreno práctico, da origen a un nuevo modelo de acción, la técnico-instrumental, que, por una parte, amenaza diluir la ética en subjetivismo irracionalista y, por otra, en despojar a la naturaleza de toda dimensión axiológica.

Mientras Leibniz aún razonaba a partir de convicciones como que la naturaleza se rige por un orden racional que la convierte en buena y valiosa, que las leyes naturales reflejan ese orden y que la ciencia formula a su modo aquella bondad, el subjetivismo de la modernidad encontraba en Kant su profeta y en los idealismos de la subjetividad su prolongación. El genial proyecto ético de Kant concentra sus esfuerzos en proclamar la autonomía del mundo moral frente a una naturaleza entregada al determinismo de las leyes físicas 6 . Poner límites a la racionalidad científica y conceder mayor amplitud a la razón práctica permitió a Kant, sin embargo, mediante el demiurgo de la libertad, mantener aquellos elementos de la tradición, tales como Dios

4 Tomás de Aquino asigna a la naturaleza cierta autonomía al atribuirla una consistencia y capacidad de obrar recibida de Dios, un ordo praeceptorum legis naturae, que se corresponde con el ordo rerum naturalium, cuya normatividad la razón no crea pero sí es capaz de descubrir. Cf. Summa Theol. I-II, 91, 2-3; 94, 2.

${ }^{5}$ Es dogma que triunfa desde Descartes al Idealismo alemán. G. E. Fichte ha llevado esta tesis al paroxismo al interpretar la realidad del mundo como mera objetivación de la actividad reproductora del sujeto. Cf. Grundlage der gesammten Wissenschaftslehre, 1794, $2 .^{a}$ ed., 1798, en Fichtes Werke, I. Herausg. von I. H. Fichte, Berlín, 1971, pp. 96 ss. Grundriss des eigenthümlichen der Wissenschaftslehre, 1795, en Ibidem, pp. 335 ss.

${ }^{6}$ La naturaleza, abandonada a sí misma «sich selbst überlassenen Natur» (Allgem. Naturgeschichte und Theorie des Himmels en Akademische Ausgabe, 1, 364), según convicción deísta, deja de ser portadora de valores y dignidad y, por el contrario, desde el punto de vista ético, es contemplada como natura corrupta, según tradición luterana, $y$, por ello, en modo alguno portadora de una legalidad capaz de fundamentar normas morales que heterónomamente impongan deber a la conciencia. 
o la felicidad, en el misterioso reino del noumenon a resguardo de la crítica científica. Su proyecto ético rezuma subjetivismo polarizado en un yo autónomo, soberano, autolegislador y autoconsciente. Las filosofías de la conciencia, de Descartes a Kant, como Husserl magistralmente ha descrito, escenifican un proceso en el que los elementos axiológicos constituyentes del mundo moral, o tienden a ser relegados a la esfera de un sujeto abstracto o corren el riesgo de ser anulados por el objetivismo científico-metodológi$\mathrm{co}^{7}$. El mundo natural, confinado al reino de la res extensa, es puesto entre paréntesis por un sujeto, que o se autoproyecta a sí mismo en una objetividad idealizada o capitula ante una objetividad incapaz de controlar. Desde esa perspectiva la modernidad diseña una racionalidad práctica en la que la subjetividad, ya bajo forma de creencia, ya de razón, ya de libertad o ya de emotividad mantiene la hegemonía del hombre. La naturaleza, por el contrario, reducida a objeto útil, aparece como víctima de los intereses egoístas del sujeto, tal como testimonia el utilitarismo. En cualquier caso, los presupuestos de los modelos de la subjetividad sustituyeron una naturaleza cualificada con valores por otra interpretada según los principios del mecanicismo clásico. Eliminados los aprioris metafísicos y religiosos como fundamentos de una cosmología axiológica, el origen de la obligación moral debió de ser buscado en otra parte, en los aprioris de la subjetividad.

Es de todos conocido que la interpretación teleológica de la naturaleza fue sometida durante la modernidad a un lento proceso de erosión. A medida que la ciencia moderna construye su imagen del mundo y diseña un sistema de leyes que regulan su comportamiento mecánico, la teleología se topa con dificultades crecientes. El funcionamiento del cosmos ad instar horologii se rige por las leyes de la necesidad y no por valores de la libertad. A un hombre tan perspicaz y ecuánime como B. Spinoza no le repugna que los animales, privados de sentimientos y de vida, puedan ser maltratados al arbitrio del hombre utilitarista ${ }^{8}$. La fundamentación religiosa de una axiología inmanente a la naturaleza se debilita a medida que las ciencias naturales explican nuevos segmentos del cosmos. En correspondencia con los avances de la físico-matemática, la cuantificación y formalización del mundo natural destruye los presupuestos de una relación axiológica: ética, estética y religiosa, entre el hombre y la naturaleza. No son valores ni relaciones de respeto y solidaridad las que median entre el hombre y el medio natural. Priman las de dominio y explotación mercantil. La conclusión es obvia: una naturaleza despojada de valores esta condenada a carecer de derechos. Si el mundo está puesto a disposición del hombre (Zuhandenes) como Heidegger ha enfatizado 9 , las decisiones irracionales de aquél pueden transformar su uso

7 Die Krisis der europäischen Wissenschaften und die transzendentale Phoenomenologie, La Haya, 1976, pp. 70 ss., 83 ss. y 88-91.

8 Ética, parte III, prop. 57 y parte IV, prop. 37.

9 Sein und Zeit, parag. 22. 
en abuso. Lo cual en época de imperialismo tecnológico puede conducir a catástrofes. Contra tal degradación de la naturaleza, la ética medioambiental reclama una naturaleza poblada de valores y dignidad y, en consecuencia, dotada de competencias normativas. Aunque parezca paradójico, el denostado iusnaturalismo retorna con nueva vestimenta bajo presión de la crisis ecológica y de los desequilibrios introducidos por la civilización técnicoindustrial.

\section{Dos fracasos contemporáneos de reconstrucción de la razón práctica}

En época reciente, tras el debilitamiento de la metafísica y de la religión, el liberalismo y el socialismo marxista habrían sido los dos intentos más relevantes de reconstrucción de la razón práctica ${ }^{10}$. Se corresponderían con las dos clases sociales que, a partir de la Ilustración, se disputan la hegemonía ideológica en Occidente: burguesía y proletariado. Porque descartada la naturaleza como titular de valores y fundamento de normas, la ética y el derecho se vieron obligados a buscar nuevas formas de legitimación. La éti$\mathrm{ca}$, desenganchada, por una parte, de la metafísica y de la religión y, por otra inviable, su construcción sobre el modelo epistemológico de las ciencias de la naturaleza, se encontró al albur de los bandazos culturales. A la razón práctica no la restaron otros refugios que o los subjetivos de la decisión, la emotividad y la intuición, o los colectivos del totalitarismo social o de la verdad pragmática.

El debilitamiento de la ética se acentúa con el divorcio entre el ámbito de la vida privada, espacio donde se ubican las preferencias axiológicas personales y el ámbito de la vida pública, regido por una racionalidad sociológica de carácter objetivo. Se dieron por buenas una serie de dicotomías: éticaciencia, valores-hechos, moral-sociología..., que impusieron una reubicación perniciosa de la ética en los lares del irracionalismo existencial, decisionista o emotivista. $Y$ profetas del irracionalismo moral no faltaron: Nietzsche, Weber, Scheler, Heidegger, H. Albert... Entre nosotros J. Muguerza. En todos los casos se parte de la convicción de que los juicios de valor no son susceptibles de fundamentación racional 11. Las valoraciones quedarían confinadas al ámbito de la subjetividad, el cual, al carecer de aquella objetividad científica imprescindible para una verdad contrastada, estaría dominado por decisiones irracionales de impronta existencial. La remisión por boca de L. Wittgenstein de lo ético y de lo místico a la región de la que el lenguaje científico no puede hablar coincide en el fondo con el

\footnotetext{
10 Cf. V. Hoesle, Die Krise der Gegenwart und die Verantwortung der Philosophie, Munich, 2. ${ }^{\text {a }}$ ed., 1994, pp. 80 ss. y 95 ss.

11 Cf. A. Cortina, Ética mínima. Introducción a la filosofia práctica, Madrid, Tecnos, 1986, pp. 83-133.
} 
decisionismo subyacente a la ética de convicciones de $\mathrm{M}$. Weber, para quien las decisiones sobre fines últimos y valores supremos escapan a la fundamentación racional. En ambas hipótesis la ética aparece tarada de skepsis con una racionalidad disminuida $12 \mathrm{y}$, en todo caso, abocada a una ineludible esquizofrenia.

El posible antagonismo entre aquellas dos esferas y la correspondiente doble moral ha servido, tanto a Apel como a Habermas, de marco de análisis de la sociedad contemporánea y de los dos tipos de racionalidad práctica que en ella predominan: la racionalidad dialógico-comunicativa y la racionalidad estratégico-funcional. El rótulo sistema de complementariedad, utilizado por Apel para caracterizar la situación filosófica de Occidente, tendría sus raíces en el malhadado cliché sujeto-objeto vigente en la epistemología moderna 13. El pensamiento occidental, de acuerdo con aquel cliché, estaría dividido en dos grandes bloques, el uno centrado en la ideología cientificista basada en el concepto objetivista de verdad. Su discurso dominaría en las ciencias de la naturaleza y en él las decisiones y juicios de valor quedarían relegados al ámbito del sujeto. Para el grupo frankfurtiano aquella dualidad se correspondería con el dualismo de sistemas sociopolíticos imperante durante gran parte del siglo Xx: el socialismo y el liberalismo. Con exceso de simplicidad, aquel dualismo ha servido a nuestros autores para encuadrar en un determinado modelo de sociedad a las principales corrientes de pensamiento del siglo que acaba de terminar, atribuyendo a las respectivas filosofías la función de ideologías legitimatorias de sistemas políticos y económicos. Del lado socialista se ubicarían las opciones de tradición marxiana, empeñadas en vertebrar la racionalidad práctica a partir de un apriori social de impronta utópica o totalitaria, en el que no tendrían cabida esferas autónomas de comportamiento segregadas de la idea moral que vertebra el conjunto. De otro lado se alinearían autores adscritos a la forma mental burguesa, tales como M. Weber, M. Heidegger, H. Albert o incluso K. Popper, coincidentes, en este caso, en diluir la acción moral en el decisionismo de la libertad, en el irracionalismo de la facticidad histórica o en el emotivismo del sujeto.

Aquel sistema de complementariedad se atiene a sendos tipos de racionalidad de la acción humana con largas implicaciones morales ${ }^{14}$. De partida, se rompe la unidad de la razón práctica y se establecen dualismos entre hechos y valores, ciencia y ética, que acotan compartimentos heterogéneos: el de la esfera privada en el que se ubican las decisiones morales en régimen de libre decisión y el de la vida pública, en el que impera la facticidad socio-

${ }^{12}$ Cf. J. M. ${ }^{\text {a }}$ G. ${ }^{a}$ Gómez-Heras, «El "plus" de libertad en las decisiones últimas y su irreductibilidad a razón teórica, sociológica o jurídica» en Ética y hermenéutica. Ensayo sobre la construcción moral del «mundo de la vida» cotidiana, Madrid, 2000, pp. 282-291.

13 Cf. V. Hoesle, op. cit., pp. 80 ss., y A. Cortina, op. cit., pp. 85 ss.

14 Cf. A. Cortina, Razón comunicativa y responsabilidad solidaria, Madrid, 1985, pp. 84 ss. 
lógica y la normatividad jurídica. Si aquél aparece motivado por las convicciones del sujeto, éste se atiene a la racionalidad estratégica instrumental en vistas a las consecuencias de la acción. El sistema de complementariedad implica que la racionalidad solamente es atribuible al saber científico-objetivo sobre hechos y, por lo mismo, de racionalidad práctica solamente puede hablarse en el ámbito de la vida pública, tal como la sociología levanta acta de la misma o el derecho positivo configura su legalidad. La vida privada y los juicios de valor que motivan las decisiones carecerían de racionalidad y expresarían vivencias emotivas de los sujetos, con el consiguiente relativismo moral. El liberalismo, en este caso, aparecería como un episodio cualificado de destrucción de la razón práctica, no sólo por confinarla al ámbito del emotivismo irracional, sino también por aceptar que éste se encuentra dominado por intereses egoístas.

Pocos como M. Weber nos han legado fórmulas tan pregnantes para describir a nuestra sociedad en situación de esquizofrenia entre los valores que los sujetos prefieren y la objetividad social que se comporta con neutralidad axiológica. Su famosa tipología de éticas: ética de convicciones-ética de responsabilidad lo formula magistralmente. Con ella se pretende acotar dos esferas de la acción humana: la que corresponde al ámbito privado y la que corresponde al ámbito público. Dos tipos de racionalidad, contrapuestos, los regularían. Uno, el tipo técnico-instrumental de razón (Zweckrationalität, en terminología weberiana), según el cual la racionalidad se establece en la relación medios-fines. Una conducta resulta razonable cuando, prescindiendo de la cualificación de los valores o fines últimos que la motivan, utiliza los medios adecuados y eficaces para la obtención de determinados resultados. La calidad moral de los fines perseguidos no se toma en consideración, dado que tal asunto pertenece a las valoraciones del sujeto y por lo mismo depende de una decisión de su voluntad. Es la libertad y no la razón la que en último termino determina una decisión. Otro, el concepto valorativo de racionalidad (Wertrationalität, en terminología weberiana), según el cual la acción del hombre se enjuicia a partir de los valores y convicciones que una persona profesa. Si aquél considera prioritariamente las consecuencias de una acción, éste se rige ante todo por los principios que la orientan 15 .

La progresiva evacuación de la razón axiológico-valorativa por la razón técnico-instrumental implicó un componente de ambigüedad moral que inevitablemente daría lugar a crisis de sentido de nuestra civilización. En efecto: por una parte, la emancipación de sectores de la vida práctica, tales como la política o la economía, respecto a criterios morales normativos de más alto rango, y la implantación progresiva de formas de racionalidad instrumental por las diferentes ciencias en sus propios dominios, proporcionó

${ }_{15}$ M. Weber, Wirtschaft und Gesselchaft, I, 2.4. Cf. W. Schluchter, Religion und Lebensführung. Studien zu M. Webers Kultur und Werttheorie, I-II, Frankfurt a. M., 1988, passim, y J. M. ${ }^{\text {a }}$ G. ${ }^{\mathrm{a}}$ Gómez-Heras, Ética y hermenéutica, pp. 279 ss. 
altos niveles de eficiencia y resultados exitosos en los diferentes campos de acción. Esta praxis del éxito y de la eficacia, sin embargo, se desarrolló a veces a costa de valores morales, estéticos y religiosos, que achicaron considerablemente la dimensión moral de las acciones y decisiones humanas. El proceso de sustitución de la razón axiológica por la técnico-instrumental determina que lo razonable sea visto como aquello que a corto plazo posee eficacia y aporta resultados. La consecuencia más relevante de tal proceso consiste en que el mundo moral, tanto del individuo como de la sociedad, construido sobre valores, convicciones y creencias y adscrito al ámbito de la libertad, es progresivamente relegado a la privacidad mientras la objetividad sociológica de la política o de la economía se entrega a estrategias orientadas al éxito ${ }^{16}$. De ese modo, paradójicamente, el problema moral se retrotrae a planteamientos que tuvo muchos siglos atrás y que dieron ocasión a los duelos dialécticos entre Sócrates y los Sofistas.

La pérdida de potencia especulativa de los sistemas postidealistas y el progreso imparable del positivismo y del empirismo metodológicos en las ciencias sociales y naturales allanó el camino a la tesis de la neutralidad axiológica de la ciencia. A partir de 1830 no sólo se erosiona la percepción moral del mundo cultural, sino también del mundo natural. Los esfuerzos de Hegel por superar el formalismo abstracto de la moralidad kantiana afectan al mundo histórico-social (familia, sociedad, Estado), pero no al mundo de la naturaleza ${ }^{17}$. La filosofía romántica de la naturaleza, proclive a la concepción organológica de la misma, tal como Goethe y Schelling intuyeron, no logra contrarrestar el empuje del empirismo científico ${ }^{18}$. Pasada la fiebre romántica, el mundo tiende a ser visto como un universo de hechos y datos y no de valores. Mientras la cultura se redescubre a sí misma como historia y acontecer, pugnando dos modelos: el de una historia a lo Hegel o Marx como metarrelato con sentido y la tradición positivista, como secuencia de hechos unidos meramente con conexiones causal-explicativas, la naturaleza es abandonada al neutralismo axiológico de las ciencias naturales y, por ello, entregada al poder de la explotación tecnológica industrial. Refugiada la razón práctica en la subjetividad del individuo, solamente se requería descubrir aquel sujeto como sede de la irracionalidad inconsciente y de las vivencias de la nada, para que la ética naufragara en nihilismo. Fue la obra de Nietzsche y de Freud.

Desde otro punto de vista, no parece aventurado atribuir al modelo burgués-liberal la paternidad del utilitarismo. Tanto menos aventurado si se aso-

16 Cf. V. Hösle, op. cit., pp. 44 ss.

17 La naturaleza hegeliana carece de entidad sustantiva. Se reduce a mera entidad fenoménica, a «ser lo opuesto a la Idea», a «exteriorización del Espíritu absoluto». Cf. «Naturphilosophie», en Werke, ed. H. Glockner, 9, 31 y Wissenschaft der Logik, en Ibidem, 4, 211.

18 Anticipando posiciones de la ecología profunda (deep ecology) y en polémica con Kant, Schelling percibe la naturaleza como un «organismo universal», dotado de espíritu inconsciente y portador de racionalidad. Cf. Ueber den Ursprung des allgemeinen Organismus en Werke, M. Schroeter (ed.), I, pp. 559 ss. 
cia a la tradición cultural anglosajona y a la simbiosis acontecida en ella entre ciencia, técnica e industria de consumo. Ahora bien: la civilización técnico-industrial contempla la naturaleza como objeto carente de valores propios y como material sometible al uso y abuso de los humanos. Desde tal convicción se allana el camino al bienestar consumista. La opción utilitarista aparece para algunos, con rechazo enérgico por parte de otros, como vía pertinente para asumir, desde sus presupuestos previos, buena parte del ethos ecológico. Contra las éticas utilitarias se ha argumentado con acritud que no rebasarían los límites de una ética egoísta al proclamar como valores prioritarios el bienestar y la utilidad, olvidándose de riesgos futuros y de presentes injustos. La naturaleza sería percibida por el utilitarista como mero depósito de materias transformables en orden al mercado. De suyo, sin embargo, el modelo utilitarista de conducta no implicaría obstáculos incorregibles en orden a satisfacer las demandas del ethos ecológico, siempre y cuando los valores de la naturaleza fueran respetados y mantenidos. La universalización de éstos podría satisfacer el principio de justicia social e intergeneracional. Incluso el criterio utilitarista permitiría ampliar al campo de la relevancia moral a los vivientes no humanos. De hecho, un modelo utilitarista de ética medioambiental ha sido defendido por ensayistas prestigiosos de estos temas ${ }^{19}$, quienes encuentran en aquél capacidad adecuada para ampliar el campo moral conforme a las exigencias de nuevos tipos de acción y de cambios sociales previsibles. La capacidad del utilitarismo para solventar los problemas del mundo cotidiano aventaja en mucho a los modelos abstractos de impronta idealista vigentes en la tradición kantiana. Si en ésta se facilita el cumplimiento de requisitos formales como la universalización de normas, el abstractismo obstaculiza las soluciones concretas. Las exigencias de un ethos medioambiental en ámbitos como la economía o la política, por el contrario, encuentra en el modelo utilitarista soluciones más realistas y cercanas al mundo empírico social. La objeción de mayor peso contra el utilitarismo medioambiental, de igual modo que contra cualquier utilitarismo, hay que buscarla en aquel tipo de racionalidad estratégico-instrumental, que desvincula la acción humana de valores más altruistas, hipotecándola a éxitos y a utilidades inmediatas.

Pero el siglo que acaba de terminar presenció con estupor otra gran aventura, mezcla de utopía y de tragedia, de reconstrucción de la razón práctica: el marxismo. En él las valoraciones y decisiones aparecían impregnadas de motivaciones no reducibles a la razón calculadora e instrumental. El expresionismo conceptual de E. Bloch 20 y el posterior éxito del grupo de los

${ }^{19}$ Cf. J. Nida Rumelin, von d. D. Pfordten, Oekologische Ethik und Rechtstheorie, BadenBaden, 1995, p. 27, notas 17-18, en donde se hace referencia al utilitarismo ecológico de D. Birnbacher, Verantwortung für zukunftige Generationen, Stuttgart, 1988.

${ }^{20}$ El principio esperanza I-III. F. González Vicen (trad.), Madrid, 1977. Cf. J. M. ${ }^{a}$ G. ${ }^{a}$ GómezHeras, Sociedad y utopía en E. Bloch. Presupuestos ontológicos y antropológicos para una filosofia social, Salamanca, 1977. 
Frankfurtianos mostraron que la etapa postburguesa de la cultura tocaba a su fin. En una sociedad profundamente injusta, los valores morales derivaron hacia etéreas e irrealizables utopías. Pero la huida hacia la irrealidad no exime de hacerse preguntas de difícil respuesta. ¿Por qué el marxismo logró un éxito tan amplio a pesar de su dogmatismo? ¿por qué ejerció aquel poder de seducción sobre gran parte de la intelectualidad y del arte? Tres hipótesis de interpretación aparecen como plausibles: a) la seducción del marxismo se explica por su capacidad para fundamentar valores y normas en sintonía con las aspiraciones de una sociedad y la correspondiente habilidad para construir una lógica práctica coherente; $b$ ) además de su compromiso con la justicia, el marxismo pretendió integrar en un sistema social el pathos moderno por la ciencia y la técnica, presentándose ante el mundo como adalid del progreso; $c$ ) en época de creciente laicismo, construye un metarrelato del acontecer en el que ya no eran Dios o el individuo autónomo las instancias legitimadoras del sentido de la historia, sino la misma humanidad embarcada en un proceso necesario de autorredención 21.

El marxismo, en primer lugar, supo conferir un sentido histórico a la praxis humana, es decir, construir una racionalidad práctica coherente. Si a la ética aristotélica subyacía una metafísica del ser y al cristianismo una teología de la divinidad, al marxismo subyace una ontología del ser social que no por estar historificada, a lo Hegel, se salvaba de vulnerar las distancias que a partir de Hume la falacia naturalista denuncia en toda homologación del ser con el deber. Al marxismo subyace una ontología teleológica de la naturaleza no menos intensa que la presupuesta en el aristotelismo o en su teologización tomista. El pathos en pro de la visión científica del mundo queda integrado, de ese modo, en una visión más global de la realidad. Y que el materialismo dialéctico de la ortodoxia marxista pretendiera compensar aquella ontología naturalista con el protagonismo de la sociedad proletaria en la historia no empece el cumplimiento de aquel axioma marxiano, tan antikantiano por lo que a la ética concierne, que «no es la conciencia la que determina al ser (social), sino el ser (económico) el que determina a la conciencia» 22. La historificación de la ontología clásica por parte de Hegel y su reconversión social por Marx no cambia, en este caso, la sustancia de la relación ser-deber. El dualismo ser-deber es tan ajeno al marxismo, si bien perspectiva diferente, como a la tradición aristotélica. Visto, por tanto, desde la metaética, el marxismo incurriría en una modalidad de falacia naturalista, la falacia socio-económica, tan criticable en su déficit de libertad, como la naturalista de Moore en su exceso de determinismo. Pero exista o no falacia, lo que ciertamente existe es una naturaleza de las cosas a la que corresponde un valor moral.

El materialismo histórico diseñó una filosofía social de amplios vuelos en la que cambio social y progreso moral aparecían maridados. No son

${ }^{21} \mathrm{Cf}$. los análisis de V. Hoesle, op. cit., pp. $65 \mathrm{ss}$.

22 MEW, 13, 8. Cf. J. M. ${ }^{\mathrm{a}}$ G. ${ }^{\mathrm{a}}$ Gómez-Heras, op. cit., pp. 59 ss. 
pocos, incluso, quienes, en una sociedad intensamente secularizada, han percibido el marxismo como una religión/sucedáneo de salvación, en la que la vieja teología de la historia de matriz judaica reaparecía en vestimenta dialéctica y con amplios componentes revolucionarios, proféticos y soteriológi$\cos 23$. Pero aquella inserción de la ética y de la política en una filosofía de la historia reportaba, por igual, ventajas y desventajas. La evasión permanente hacia el futuro utópico de una sociedad sin clases le dotaba de atracción a través de un discurso impregnado de profetismo retórico. La atracción, sin embargo, resultaba ineficaz, dado que su legitimación del deber desde un futuro ideal resultaba operante solamente en los profetas y místicos de la causa. La racionalidad práctica naufragaba bajo presión del dogmatismo autoritario. Las estructuras totalitarias del marxismo, impuestas en gran medida unas veces por una interpretación determinista de la historia, otras por el mesianismo profético, acabaron derrumbándose ante un hecho de evidencia cotidiana: el avance y expansión de la libertad a la sombra de los Derechos Humanos.

Es de reconocer, sin embargo, que un futuro previsto como realización del ideal de justicia proporcionaba un eficaz referente para ejercer la crítica a un presente histórico deficitario en aquélla. Pero tanto la utopía escatológica, sin embargo, como la retórica profética se diluyeron en una ensoñación incapaz de aportar concreción historia a las esperanzas de redención social. De Marx hemos aprendido que la Ilustración abstracta cultivada por los idealismos burgueses de poco sirve si no se traduce en compromisos morales de justicia. La escatologización de la historia diseñada por E. Bloch y compartida por los Frankfurtianos cargaba sin duda el acontecer de esperan$\mathrm{za}$, pero también de fuga hacia la ensoñación diurna. La anticipación de un futuro tan deseado como improvisado difícilmente podía cumplir, además, con el principio de universalización de normas y valores erigido a partir de Kant como soporte de toda vida democrática y plural. La esperanza de la justicia chocaba inevitablemente con la realización presente de la libertad. El marxismo no se percató de que proclamar un futuro utópico en instancia que determine la acción histórica del hombre constituye un atentado contra la libertad del mismo calibre que atribuir aquella función a un pasado absolutizado. En ambos casos, una concepción determinista del acontecer acaba erosionando la autonomía kantiana de la conciencia. Tan lesionada se sentiría ésta por la fatalidad de un tiempo impuesto por la tradición como por un acontecer necesario impuesto por un futuro utópico.

La interpretación marxista de la razón práctica no sólo adoleció de dogmatismo criptoteologico, sino que asumió graves lastres ideológicos ya descalificados por la historia. De ahí su incapacidad para construir una raciona-

${ }^{23}$ Cf. el precioso librito de K. Loewith, Weltgeschichte und Heilsgeschehen. Die Theologischen Voraussetzungen der Geschichtsphilosophie, Stuttgart, 1967, pp. 38-54. Existe trad. al casteIlano con el título El sentido de la historia, Madrid, 3. ${ }^{a}$ ed., 1968. 
lidad equilibrada que habilitara espacios para la expresividad del sujeto libre y, por lo que a nuestro asunto respecta, que evitara aquella filosofía de la historia de impronta hegeliana, que obstaculizaba recuperar la dimensión perdida, el mundo de la vida natural, que entra con fuerza en el escenario del naciente siglo XXI. Los gérmenes de la nada destructiva a los que Hegel concede tanto protagonismo en su dialéctica de la historia escenificaron su poder corrosivo en el marxismo, al menos en dos de los subsistemas que Habermas atribuye al mundo de la vida social: a) la pérdida de tradición y herencia cultural a causa del fervor revolucionario; $b$ ) un enorme déficit de tolerancia y de respeto a la dignidad de la persona con pérdida del expresionismo de la subjetividad personal. La naturaleza marxiana aparecía anegada en determinismo, tanto o más que la sociedad en la historia 24 . De ahí que el reduccionismo economicista obnubilara muchas mentes que creyeron homologar la solución de los problemas económicos con la solución de los problemas ético-políticos. El que no se lograra resaltar que el ser humano consiste en algo más que en el homo oeconomicus desembocó en una equiparación trágica entre racionalidad práctica y realidad económicosocial y, por lo que a nuestro tema concierne, en ceguera para el problema ecológico. Los desastres a que tal ceguera dio lugar - Chernobil aún nos los recuerda - reafirmaban la interacción ineludible entre las patologías sociales y las patologías medioambientales.

\section{El talante moral de una época: la polis descentrada}

Al regresar Ulises a Ítaca halló intrigas y guerras. Pero también encontró valores morales, sobre todos la fidelidad de su esposa, Penélope, tejiendo y destejiendo el tiempo de la espera. No es nuestra patria Ítaca ni esperamos a Ulises pero también hoy para nosotros, en una sociedad escéptica, persiste la añoranza hacia el deber moral: ¿qué puede continuar siendo racionalmente valioso? Ante los desplazamientos que la civilización científico-tecnológica está provocando se suele hablar de cultura descentrada. Sería, sin embargo, más sensato hablar de búsqueda de un nuevo centro y del tipo de racionalidad correspondiente ${ }^{25}$. Porque lamentar el debilitamiento de otras formas de razón práctica no significa destrucción de la misma, sino meros avatares de la odisea de la humanidad en busca de sí misma. Las preguntas formuladas por las dos grandes tradiciones de la reflexión occidental, el clasicismo gre-

\footnotetext{
24 Cf. F. Engels, Dialektik der Natur en MEW, 20. Véase también A. Schmidt, Der Begriff der Natur in der Lehre von Marx, Frankfurt a. M., Frankfurter Beiträge zur Soziologie, 11, 1962.

${ }_{25}$ Cuando G. Lipovetsky, en La era del vacío. Ensayos sobre el individualismo contemporáneo. (Trad. al castellano en Anagrama, Barcelona, 9. ${ }^{\mathrm{a}}$ ed., 1996), detecta en la cultura postmoderna el ocaso de los valores y del deber, la apreciación es acertada pero precisa de matización. A saber: que en vez de ocaso del deber habría que hablar de surgimiento de una nueva constelación de valores y deberes en una humanidad que los echa de menos y que no cesa de buscarlos.
} 
colatino y la religiosidad judeocristiana, mantienen tozudamente su vigencia, a veces reformuladas con vestimenta secular, frente al nihilismo escéptico. Éste aporta caldo de cultivo a la banalidad de una sociedad en la que el nihilismo axiológico y el cinismo ético van de la mano. La pérdida de la fe en cualquier sistema de valores está erosionando la convivencia ciudadana y la sombra de la duda planea no sólo sobre las ideas y los dioses. Se alarga sobre todo lo que el lenguaje nombró con la palabra felicidad.

Existen afinidades profundas entre aquellos pensadores que han aventurado un diagnóstico de nuestra situación cultural: Nietzsche, Weber, Husserl, Lukacs, Heidegger... Los rótulos por ellos acuñados: inversión de todos los valores, desencantamiento del mundo, crisis de la civilización científica, eclipse de la razón, nihilismo postmetafísico... remiten a una misma patología: la crisis de la ética ${ }^{26}$. Sobre contrafondos muy diferentes cada uno de los nombrados se refieren a la descomposición de la racionalidad práctica en aquella dimensión que le dio sentido y legitimó los imperativos morales. Nihilismo, desencantamiento o irracionalidad no significan otra cosa, en este caso, que situar al hombre en un solar, carente de aquellos cimientos sobre los que la civilización occidental tendió a dar sentido a la vida y a la cultura.

La crisis de la ética acontece de modo sutil en nuestra civilización técnico-industrial. Mientras a través de convulsiones dolorosas la humanidad va consolidando un mínimo de valores ético-políticos, tales como la vida, la paz, la libertad, la igualdad, la solidaridad, la justicia, etc., e incluso sanciona su estatuto jurídico en las sucesivas formulaciones de los Derechos humanos, frente a tal progreso moral se alza una sociedad de consumo y el correspondiente entramado mercantil-industrial que, escamoteando valores y normas, se erige en auténtico gestor y protagonista de una civilización enferma. Las conciencias de los gobernantes y gobernados obtienen tranquilidad en sus comportamientos públicos apelando a los Derechos Humanos y, mientras tanto, el nihilismo axiológico se implanta al amparo de intereses inconfesables. Coexisten en tal situación dos racionalidades prácticas: la del aparentar ficticio y la de la praxis real que impiden que el mundo de la vida cotidiana se impregne de sustancia moral. La gravedad de la situación se incrementa cuando la ciencia y la técnica, de suyo nacidas con la nobilísima finalidad de promover el progreso y el bienestar de la humanidad, se convierten en aliados serviles de intereses egoístas y de poderes irracionales. Paradójicamente, tanto la pasión por la objetividad del cientificismo como la irracionalidad de una existencia exasperada por parte de los existencialismos, condujeron a la destrucción de aquella racionalidad axiológica sin la que la ética necesariamente se agoste. La ciencia y la técnica se mostraron incompetentes para rellenar el vacío axiológico dejado por la metafísica y la religión. Las preguntas ¿qué debo hacer? o ¿qué sentido tiene la vida huma-

26 Véase J. M. ${ }^{a}$ G. ${ }^{a}$ Gómez-Heras, Ética y hermenéutica. Introducción, pp. 41 ss. 
na? restaron sin respuesta. La racionalidad axiológica, menospreciada por la ciencia, se debilitó y con ella la fortaleza del deber y del compromiso morales 27 . Las formas de racionalidad técnico-utilitarias campean por sus fueros dando lugar a lo que Habermas ha denominado colonización del mundo de la vida social y a las patologías subsiguientes 28 . El sistema social tiende al desequilibrio y a la inestabilidad por carencia de principios de legitimación ética y política. Por lo que concierne a una ética medioambiental, la situación se traduce en la irresponsabilidad de quienes practican una conducta cotidiana convencidos de que los recursos naturales son inagotables y consecuentemente expolian con voracidad a la naturaleza.

El debilitamiento de los dos fundamentos tradicionales de la racionalidad práctica: la metafísica y la religión, se vislumbra como uno de los eventos más relevantes de nuestra época. Se pierden aquellas instancias legitimadoras de valores y normas mientras una sociedad positivista rechaza nuevas formas de fundamentación moral. Con el debilitamiento de aquéllas se allana el camino para el escepticismo y el relativismo morales, sin que en nuestros días las reconstrucciones del sujeto moral sobre bases kantianas hayan logrado aceptación generalizada. El uso de fórmulas como dignidad de la persona o Derechos Humanos para cimentar las ideas de deber y responsabilidad, aunque hayan permitido progresos en cuanto al incremento de tolerancia o de respeto a la esfera privada, no se han sedimentado en un mundo moral de alcance universal. La seducción que sobre la cultura burguesa ejerció el principio de libertad no logró evitar la degradación de esa libertad en egoísmos inconfesables. La anomía de la sociedad permisiva ha solido ir de la mano de la decadencia del orden y de la norma. Erosionados ambos por los excesos de permisividad de las sociedades pluralistas, la anarquía muestra su verdadero rostro en el poder corrosivo que segrega frente a toda forma de racionalidad, en especial la moral. La primera víctima ha venido siendo el medio ambiente natural. A este propósito, el indiferentismo del escéptico y el libertinaje del cínico se prestan recíprocamente inestimables ayudas.

Bajo presión de la secularización de la sociedad y del pluralismo multicultural también el cristianismo se ha debilitado como sistema de legitimación moral. La religión ha dejado de ser centro de la ciudad descentrada. La erosión del cristianismo se debió en parte a la escasa sensibilidad de las iglesias para la forma mental científica de la modernidad y a los recelos hacia un sujeto emancipado y libre, convertido en protagonista de la cultura bur-

\footnotetext{
27 V. Hoesle analiza agudamente (en op. cit., pp. 28 ss.), el «espíritu de nuestra época» y la búsqueda de nuevos contenidos por parte de los colectivos, que, invalidados Marx, Nietzsche o Sartre como ídolos convencionales de un progresismo innovador de izquierda, tornan los ojos al ecologismo como referente de una nueva conciencia cultural.

28 Teoría de la acción comunicativa, II, M. Jiménez Redondo (trad.), Madrid, 1987, pp. 215 220. Sobre el fenómeno de la colonización del mundo de la vida social por parte de la racionalidad técnico-instrumental, cf, J. M. ${ }^{a}$ Mardones, Razón comunicativa y teoría crítica, Bilbao, 1985 , pp. 219 ss.
} 
guesa. Las tradiciones religiosas se mostraron recelosas ante la nueva constelación de valores que la modernidad instauraba. La autonomía del sujeto moral, con la peculiar racionalidad que despliega, resultó difícil de digerir a una religiosidad anclada en la tradición y en el paternalismo. Ideas de origen cristiano, sin embargo, tales como la dignidad de la persona, cimentada sobre la creencia en el hombre creado a imagen de Dios, mantuvieron e incluso incrementaron su vigencia, si bien secularizadas en el encuadre ideológico del pensamiento laico ilustrado. Tal proceso, rechazado con actitud apologética por parte del cristianismo católico, encontró, sin embargo, mayor receptividad en el cristianismo reformado, cuya fase ilustrada había iniciado un proceso de moralización de la religión, proceso consumado por Kant, en el que los compromisos dogmático-cognitivos del cristianismo se difuminaban a la par que adquirían relevancia los práctico-morales 29 .

La pérdida de poder legitimador del orden moral por parte de la religión no sólo se vinculó a los recelos de las iglesias ante los progresos de la ciencia, sino también al retraso de éstas en la construcción de una conciencia social y democrática. Los tópicos que presentaban a la religión como aliada ya del conservadurismo, ya de la burguesía capitalista, calaron en lo más profundo de la conciencia popular, y los conflictos sociopolíticos posteriores a la revolución francesa diseñaron dos frentes en los que la religión aparecía alineada con las tendencias que rechazaban aquella racionalidad sociopolítica sobre la que la democracia cultivaba los valores de la libertad y la tolerancia. Ante los avances de la secularización, la religión con frecuencia no estuvo a la altura de los tiempos, no sin que a ello contribuyeran los excesos de un laicismo a menudo jacobino. En todo caso, la religión apareció como aliada de los poderes reaccionarios, provocando actitudes antirreligiosas en las fuerzas progresistas. El ateísmo teórico de algunos círculos intelectuales y la subsiguiente crítica religiosa encontró su correspondiente sociológico en la irreligiosidad de las masas.

\section{Reaperturas del problema moral}

Pero ni el escepticismo axiológico de analíticos y existencialistas ni la credulidad de hermeneutas y utópicos lograron aportar suficientes presupuestos desde los que se pudiera reconstruir una razón práctica a la altura de la crisis moral de la civilización técnico-industrial. La ética medioambiental, por tanto, se pregunta si, dejado atrás el complejo moderno de Narciso, no debería plantearse el problema moral mas allá del alcance dado al mismo

\footnotetext{
29 Sobre la erosión del cristianismo como sistema de legitimación moral cf. V. Hoesle, op. cit., pp. 51 ss., y en lo concerniente a una ética medioambiental, E. Drewermann, Der tödliche Fortschriftt. Von der Zerstörung der Erde und des Menschen im Erbe des Christentums, Freiburg i. B., 1991.
} 
por el antropocentrismo de la modernidad. De ahí que se escuchen cada vez con mayor insistencia voces que afirman que si el modelo de ética del siglo XIX estuvo centrado en la idea de libertad del sujeto, modelo que en su formulación kantiana hizo las delicias de la cultura burguesa, y que si la ética del siglo XX estuvo sustentada sobre los ideales de la justicia social, la ética del entrante siglo XXI debería vertebrarse en torno a la racionalidad ecológica, dada la urgencia y amplitud del problema medioambiental.

La cuestión moral hace acto de presencia cuando aquello por lo que el conocimiento se pregunta, además de ser descubierto como un hecho a explicar, es estimado como un valor a preferir. Si las cosas, además de como objetos, son percibidas como valores, entra en el proceso del conocimiento el aprecio y el desprecio, la decisión y la libertad. Y a la hora de salir de la perplejidad que precede a toda decisión, surge una razón y unas normas que convierten las decisiones en deber y responsabilidad. Porque se trata de aceptar que la razón moral también tiene competencias para emitir valoraciones sobre un desarrollismo consumista cuando se encuentran en peligro tanto la naturaleza como la humanidad. Si en el proceso de conocimiento se reduce la relación entre el cognoscente y lo conocido a medir, cuantificar o transformar, la naturaleza quedaría reducida a mero objeto de explotación despojada de valor en sí misma. Con acierto Husserl denunció en su día, el objetivismo epistemológico en el que desaparecen el mundo vivido del cognoscente y las experiencias precategoriales axiológicas de los mismos agentes ${ }^{30}$. Porque el mundo moral se construye sobre la pregunta de cómo las cosas deben de ser y no sobre la constatación de cómo son. Kant, a este propósito, delimitó de forma genial dos ámbitos del saber, estableciendo las condiciones de posibilidad no sólo del conocimiento científico, sino también del conocimiento moral. No es la facticidad mostrenca que la ciencia explica, sino la ética, el criterio de lo bueno y correcto. Ella marca los contextos globales de sentido que permiten discernir la bondad/maldad de las acciones humanas sobre la naturaleza. Dando por válida, pues, tanto la denuncia husserliana de la suplantación del mundo de la vida de la conciencia por el objetivismo positivista, como la crítica de los Frankfurtianos a una racionalidad instrumental que neutraliza axiológicamente a la acción humana, restan aún importantes tareas a realizar en la reconstrucción de la razón práctica. Ante una situación de nihilismo débil, ¿cuáles son los caminos a recorrer para rellenar el vacío de valores morales? El siglo XX no ha sido parco en propuestas, algunas meras repeticiones epigonales, otras más receptivas a los estímulos de nuestra situación histórica. Desde aprioris anclados en la vida de la conciencia personal, tal como la Fenomenología propuso en pro

\footnotetext{
30 Apuntando a la psicología y a la sociología empíricas, Husserl pudo afirmar: «Blosse Tatsachenwissenschaften machen blosse Tatsachenmenschen» = «Las meras ciencias sobre hechos reducen los hombres a meros hechos», es decir, carentes de valores, Krisis der Wissenschaften, 4.
} 
de las vivencias, creencias y preferencias personales, hasta reformulaciones de la tradición deontológico-kantiana, transformada lingüísticamente en pro de una universalización de valores y normas, sin olvidar las propuestas neocontractualistas y neomarxistas, la reflexión moral contemporánea da muestras de una intensa vitalidad. Una intención común parece unir los esfuerzos: reconstruir un universo axiológico de carácter moral, capaz de rellenar con sustancia ética el vacío axiológico de la sociedad técnico-industrial. A este debate en pro de una reconstrucción de la razón práctica también se ha sentido emplazada la ética medioambiental.

De partida, es de reconocer que la reflexión moral de matriz neopositivista y analítica tenía las puertas cerradas a la ética medioambiental. La metaética, hipotecada a la forma mental cienticista, operó sobre presupuestos incapaces para valorar la dimensión moral o cualitativa de la naturale$z a$. La naturaleza explicada por la ciencia aparece reducida a mero objeto a formalizar nomológicamente y a medir cuantitativamente. Pero no como magnitud cualificada por los valores que posee y, por ende, digna de respeto. Por eso, los análisis lógicos y lingüísticos se sustentaron sobre la convicción de que no podían existir fundamentaciones racionales últimas y fuertes para los valores y las normas. La ética derivó, en ese caso, hacia posiciones emotivistas y existenciales, difícilmente conciliables con la universalidad requerida por las normas. Frente al descompromiso moral que tal actitud implica, tanto la pragmática trascendental, sea en su versión apeliana sea en su modificación habermasiana, aportó importantes materiales para reconstruir la racionalidad de las sociedades democráticas a través del diálogo y del consenso, pero careció de sensibilidad hacia el problema ecológico. Aun siendo muy relevante su contribución a nivel sociológico e incluso jurídico, y sobre ello volveremos más adelante, los problemas de fondo que tanto la metafísica como la religión pretendieron responder, restaban intactos. A este propósito, formulaciones más ambiciosas de una ética medioambiental como la propuesta por $\mathrm{H}$. Jonas, recuperó planteamientos que hacían diana en los niveles profundos del problema ecológico: copertenencia del hombre y de la naturaleza, antropocentrismo dualista de la modernidad, objetividad de los valores naturales..., es decir, aquellos que tenían que ver con el choque entre los extremos de una ética polarizada en el esquema objetividadsubjetividad.

El éxito a finales del siglo $\mathrm{xx}$ de los proyectos morales inspirados ya en el principio social, tales como los de Apel y Habermas, ya en el principio medioambiental, tales como los de H. Jonas o P. Singer, mostraron que el problema moral continuaba abierto. Mientras los modelos de moralidad diseñados por las tradiciones metafísica y religiosa muestran síntomas de debilidad, nuestra época no renuncia a una ética postmetafisica basada sobre aquellos valores que garantizan la pervivencia de la humanidad y la convivencia entre los hombres. Una reconstrucción del sistema de valores sobre el 
que nuestra cultura se sustenta buscaría legitimarse desde una doble perspectiva: la revalidación social de los mismos y el reconocimiento de que la naturaleza también los posee. La primera reconoce los derechos del hombre basados sobre el principio de justicia; la segunda, los valores de la naturale$z a$ y el respeto a la dignidad de la misma. Ahora bien: mientras la transformación social de la razón práctica kantiana ha resultado exitosa, la reconstrucción medioambiental del mundo moral, ha topado con mayores dificultades, dadas las resistencias del antropocentrismo que domina la cultura moderna. Porque, frente al subjetivismo individualista que lastra el pensamiento moderno, la ética medioambiental reivindica un mundo vivido social y natural, cuyos valores están dados con antelación a la existencia del hombre mismo. La reconstrucción ecológica de la razón práctica exige no sólo la anulación del egoísmo de especie y de sus formas contemporáneas, sino también la superación de aquellos dualismos de origen gnóstico que vician las relaciones hombre-naturaleza.

\section{Ceguera del antropocentismo social para el problema ecológico}

En un contexto de socialización de la cultura, se supone que también la ética había de efectuar su giro social. Es de notar que mientras en épocas pasadas los filósofos se venían ocupando de temas morales en tanto cuestiones estrechamente vinculadas ya a la teología, en cuanto producto de las creencias del sujeto, ya a la metafísica, en cuanto teoría sobre el ser objetivo o sobre el sujeto trascendental, en las dos últimas centurias, bajo presión de las ciencias empíricas, los innovadores de la racionalidad práctica han sido grandes contribuyentes de la ciencia social. Baste citar los nombres de Marx, Spencer o Habermas. Han proliferado bajo su impulso, por tanto, los intentos para crear una racionalidad práctica de carácter social con la que pretenden superar los lastres del egoísmo individualista del mundo burgués. Habida cuenta, pues, del debilitamiento de la metafísica y de la religión como poderes legitimadores del orden moral se potenció la vía social para reconstruir la racionalidad moral. El protagonismo de la categoría intersubjetividad en la última fase de la fenomenologia y la hegemonía posterior de la conciencia social, tal como Apel y Habermas han enfatizado, se concretó en un cambio de paradigma filosófico. La relevancia que aquella conciencia social otorga al diálogo, al discurso argumentativo, al consenso y a la universalización de normas como avales de la hodierna racionalidad práctica muestra que la herencia kantiana se mantenía vigente, si bien necesitada de procedimientos concretos para realizar la intencionalidad profunda del imperativo categórico. Se perfila, por ese camino, un procedimiento adecuado a las sociedades pluralistas contemporáneas, con el que poder desactivar mediante consenso los conflictos de valores. La validación intersubjetiva de 
normas se convierte en conditio sine qua non de su corrección social. Por eso, en una sociedad tendente, de una parte, al amoralismo y, de otra, con urgencias ineludibles de valores y deberes, se venía abriendo camino desde tiempo atrás aquella forma mental que, andando el tiempo, se postulará como ontología social ${ }^{31} \mathrm{y}$, en cuanto tal, en plataforma adecuada para construir un sistema de legitimación de valores y normas capaz de fundamentar un ámbito del deber ser no sólo en las relaciones entre los hombres, sino en las relaciones de éstos con la naturaleza. De hecho, desde el vacío nihilista anunciado por Nietzsche y los existencialistas, la cultura occidental se entregó a la ingente tarea de superar el relativismo y el escepticismo. Se consolida de ese modo la idea de un apriori social, concretado en los denominados Derechos Humanos, que asume paulatinamente la función legitimadora de la racionalidad práctica ${ }^{32}$. Los planteamientos trascendentales del subjetivismo kantiano, se complementan por su vertiente social, dado que los valores e imperativos morales no se cuecen ya en la autonomía de la conciencia personal, sino que remiten a una objetividad social con la que el hombre se encuentra como hecho histórico dado. Con ello se inicia una senda fecunda para reconstruir la racionalidad práctica en las sociedades pluralistas contemporáneas y las actitudes derivadas del nihilismo, escepticismo y relativismo entre otras, restan desautorizadas por el principio de justicia.

Tanto o más que el proyecto apeliano, la reconstrucción habermasiana de la razón práctica prolonga la crítica y oposición de sus predecesores Frankfurtianos a las cosificaciones objetivistas del positivismo alicorto y a las patologías sociales causadas por una colonización tecnológica de una sociedad dominada por intereses bastardos. Habermas, en su abigarrado fresco barroco, mezcla de erudición y de eclecticismo, aporta valiosos elementos a la crítica sociocultural. Pero el encuadre de la crítica social de sus predecesores, mezcla de filosofía de la historia marxiana, de dialéctica hegeliana y a veces de interpretación freudiana, es progresivamente desplazado a medida que cobran protagonismo el giro lingüístico y la categoría fenomenológica de mundo vivido (Lebenswelt). La teoría sociológica, en este caso, se revitaliza con el concepto clave de acción comunicativa y con ésta se potencian las virtualidades críticas respecto a los desequilibrios socioculturales causados por las colonizaciones tecnológicas. Aquel dualismo epistémico, tan del agrado de Kant, Dilthey o Weber, sirve otra vez para contraponer sendos tipos de racionalidad, en cuyo encuadre la melodía crítica suena con tonalidades novedosas aportadas por dos nuevos registros: el lenguaje y el mundo

31 Véase en este sentido la obra clásica de A. Theunissen, Der Andere. Studien zur Sozialontologie der Gegenwart, Berlín, 1965, y los esfuerzos de A. Schutz por encarrilar el problema en perspectiva fenomenológica.

32 Encajan aquí cuestiones concretas debatidas en ética medioambiental como la justicia intergeneracional o el argumento de los intereses de las generaciones futuras, que están obligando a revisar conceptos tales como quién puede ser sujeto de derechos o cuáles son las condiciones del deber y de la obligación. 
de la vida social. Desde ambos, como albaceas contemporáneos de la herencia ético-social, se enhebra una crítica inmisericorde contra el modelo de sociedad construido por la racionalidad técnico-industrial. Se prolonga, por tanto, el análisis sociocultural diseñado por la Dialéctica de la Ilustración de Horkheimer, si bien con nuevos recursos conceptuales, menos dogmáticos y aprioristas. Bajo la lupa habermasiana desfilan las formas de legitimación socio-política construidas por la reflexión burguesa, los intereses que guían los diferentes tipos de conocimiento y los alicortos horizontes con que opera una sociología empírico-funcional. Todo ello es percibido como resultado de la exaltación del cienticismo y del tecnicismo a ideologías y, consecuentemente, a principios de legitimación de las praxis política y social ${ }^{33}$. Desenmascarar el entramado que entretejen las diferentes formas de racionalidad técnico-instrumental y su opulencia en contravalores, tales como la acumulación de poder, las falsas necesidades, las capacidades de manipulación, el expolio de la naturaleza... exigía aplicar aquella estrategia del claroscuro en el que las carencias morales de una civilización fueran desenmascaradas por la acción comunicativa y, como contraoferta, recuperar aquellos valores sociales que el mundo de la vida conserva, transmite en herencia y custodia como deposito y reserva moral. Los procesos discursivos de comunicación simbólica actúan, en ese caso, a la manera de cordón umbilical que transmite aquellos valores - sedimentados por el mundo de la vida en los subsistemas de la cultura, de la cohesión social y de las vivencias subjetivas- a una sociedad tendente a organizarse conforme a los principios de la racionalidad funcional y sometida constantemente a los riesgos del poder colonizador de la razón instrumental. En cualquier caso, la retroalimentación de la civilización técnico-industrial por el mundo de valores sociales resulta ineludible para mantener ésta a salvo de patologías y desequilibrios ${ }^{34}$.

Pero la exitosa reconstrucción habermasiana de la racionalidad práctica padece un lamentable olvido: el olvido del mundo vivido de la naturaleza. Ésta carece de palabras para comunicarse o, al menos, su heterogénea locuacidad puede no afectar a los oídos de sus potenciales interlocutores. De acuerdo con el antropocentrismo moderno ilustrado y con la dialéctica hege-

33 Es relevante a este respecto el conocido ensayo de J. Habermas, Ciencia y técnica como «ideologia». Trad. de M. Jiménez, Madrid, Tecnos, 1984, pp. 53-112.

34 Como es sabido, a estos efectos Habermas explota productivamente materiales de diferente procedencia, que van desde la lingüística de Searle o de Chomsky a la hermenéutica social de K. O. Apel, con los que se lanza en tromba contra el neoempirismo metodológico de K. Popper y de H. Albert, así como contra la teoría sociológica de sistemas de Luhmann. Sobre el soporte apriorístico de la comunidad ideal de comunicación, diseña un tipo de racionalidad ético-social de carácter normativo, que, de rechazo, le permite diagnosticar las patologías de las sociedades postindustriales y los procesos de distorsión y disfunciones que las perturban. El diálogo discursivo, como procedimiento generador de aquella racionalidad comunicativa, encauza procesos de autoesclarecimiento de la conciencia social, la cual, orientada a un consenso proclamado sede de la verdad, de la libertad y de la dignidad de la persona, vehicula el reconocimiento del mundo vivido que cada interlocutor social pretende hacer valer. 
liana subyacente a la propuesta habermasiana, la capacidad de universalizar valores y normas, se atribuye en exclusiva al hombre, olvidando que también la naturaleza puede ser vehículo de universalización. En la racionalidad dialógico-discursiva de Apel y Habermas, al monopolizar el diálogo verbalizado los procesos de universalización, el componente antropocentrista bloquea toda iniciativa procedente extra muros del ámbito restringido de los humanos parlantes y cualquier expansión de la dimensión moral a segmentos extrahumanos ${ }^{35}$. Tras la socialización de la ética se mantiene larvadamente el antropocentrismo occidental o prejuicio de especie, al mantenerse intactos los intereses del hombre y desvincularlos de los de la naturaleza. Devaluada la relación hombre-naturaleza en un sistema antropocéntricosocial y mantenido el modelo sujeto-objeto como base de aquélla, los valores y las normas pierden su conexión con la naturaleza. Se intensifican ciertamente las contradicciones entre razón técnico-instrumental y acción social comunicativa en perspectiva sociológica, pero la naturaleza, excluida por incompetente para los procesos lingüísticos orientados al consenso, continúa degradada a mero objeto de interacciones sociales, sin poseer relevancia moral alguna. Ésta aparece monopolizada por la dimensión social de la vida humana. Con lo cual se incurre en un lamentable error. A saber: que emancipación social y explotación técnico-industrial de la naturaleza se contradicen. La verdad, más bien se sitúa en el otro extremo: solamente existe emancipación auténtica de la humanidad cuando la misma se corresponde con la emancipación de la naturaleza.

Habermas, en sus clarividentes análisis del mundo de la vida social, ha intentado, con talante ecléctico y tolerante, habilitar un puesto para los diferentes tipos de razón, científica, social e individual en una sociedad plural y democrática. $Y$ en época de irracionalismo y nihilismo ha logrado un tipo de racionalidad dialógico-comunicativa no dogmática. Tanto a él, pues, como a K. O. Apel adeudamos la rehabilitación de la mejor tradición ilustrada y kantiana, despojada de lastres individualistas. Su fidelidad, sin embargo, al antropocentrismo de la modernidad les ha puesto velos en los ojos para percatarse de aquella cuarta dimensión, la naturaleza, que ineludiblemente se encuentra a la base del orden, de la cultura y de las mismas experiencias subjetivas ${ }^{36}$. Los tres subsistemas de los que nos habla Mead y que Haber-

35 Cf. C. Velayos, La dimensión moral del ambiente natural, Granada, Comares, 1996, pp. 21 ss., 109 ss. y 186 ss.

${ }^{36}$ Los tres subsistemas del mundo de la vida social: cultura, sociedad, subjetividad, que Habermas, a la zaga de G. H. Mead, utiliza para interpretar los cambios sociales y las tensiones y rupturas posibles, así como para desenmascarar los procesos de colonización técnico-instrumental y las consiguientes patologías sociales, no cubren el ancho campo de la vida natural y de sus valores ni extraen las consecuencias o diagnostican los desequilibrios causados por aquellos procesos de colonización del mundo de la vida natural a través de la cuantificación, matematización e informatización. De ahí el olvido de aquella dimensión del mundo vivido por el hombre que pudiera verse afectada por la crisis ecológica y sus derivados: artificiosidad de la vida, destrucción de la naturaleza y riesgos para la misma especie humana. Pensamiento postmetafísico, Madrid, 1990, 
mas reutiliza en su estratificación del mundo de la vida: el depósito científico-cultural, el orden jurídico-social y la expresividad del sujeto, han estado bien representados en la civilización del siglo XX. Pero se ha olvidado que a caballo entre el siglo XX y el XXI emerge potentemente un cuarto subsistema, el sistema de la naturaleza o ecológico, como apriori legitimador de valores y normas. Es, por tanto, en ambos segmentos de nuestra cultura: en la socie$d a d$, en cuanto instancia legitimadora de normas, y en la naturaleza, en cuanto mundo portador de vida, valores y dignidad, en donde radica una racionalidad ética universalizable, fiel a la herencia ilustrada y respetuosa hacia una naturaleza maltratada.

De hecho, ya en un escrito temprano, Habermas había puesto serios reparos a la imagen neorromántica de la naturaleza como organismo viviente tan del gusto del ensayismo ecologista ${ }^{37}$. El texto exteriorizaba su aversión a la cosmología de la natura naturans, transmitida por el neoplatonismo judío y por el animismo cosmológico de Schelling o de Bloch. Su escepticismo ante los intentos de hermanar al hombre y a la naturaleza de forma racional se mantiene hasta su pensamiento tardío. El modelo de ética discursiva por él diseñado y el modelo de ética naturalista preferido por el ecologismo no serían compatibles ${ }^{38}$, puesto que los intereses de la humanidad y los de la naturaleza no coincidirían. La subsistencia y autoconservación del género humano exigirían el sacrificio de la naturaleza y poner animales y plantas al servicio de la humanidad. Además de esta razón de impronta antropocentrista, existiría otra de carácter histórico. A saber: que una ética de la naturaleza que recurriera a la metafísica como forma de fundamentación, implicaría un retroceso a formas de pensamiento premodernas ${ }^{39}$. Desde un punto de vista político existirían incluso indicios de que bajo vestimenta ecologista se deslicen subrepticiamiente planteamientos totalitarios. La recepción de la problemática ecológica, por consiguiente, no precisaría experimentos morales, puesto que dispone ya de un marco apropiado en los modelos antropocentristas tradicionales de ética, sin que se vislumbre la necesidad de tener que recurrir a proyectos de carácter mítico-naturalista o biológico-evolucionista. El desencantamiento del mundo a manos de la ciencia es un evento irreversible y

pp. 99 ss., Teoría de la acción comunicativa, II, Madrid, 1987, pp. 203 ss. y 215 ss.; Teoría de la acción comunicativa: complementos y estudios previos, Madrid, Cátedra, 1989, pp. 471 ss., 498. Cf. J. M. ${ }^{a}$ G. ${ }^{a}$ Gómez-Heras, Ética y hermenéutica. Ensayo sobre la construcción moral del «mundo de la vida» cotidiana, Madrid, Biblioteca Nueva, 2000, pp. 354 -367.

37 J. Habermas, «Ein marxistischer Schelling. Zu E. Bloch spekulativen Materialismus», en Merkur, 1960, pp. 1078-1091.

38 Cf. «Razón y naturaleza ¿una reconciliación al precio de un reencantamiento?», en Teoría de la acción comunicativa: complementos y estudios previos, pp. 426 ss. y 431 ss., respuesta a H. Whitebook, «The problem of nature in Habermas», en Telos, 40, 1979, pp. 41-69. K. Ott, Oekologie und Ethik. Ein Versuch praktischer Philosophie, Tubinga, 1994, pp. 99 ss., se muestra en desacuerdo con la posición de Habermas, cuyos argumentos desmonta uno por uno.

${ }^{39} \mathrm{La}$ obra de $\mathrm{H}$. Jonas, El principio de responsabilidad, así parece confirmarlo, provocando las consiguientes cautelas. 
regresiones a concepciones mítico-religiosas de la naturaleza resultan inviables. Las ciencias objetivas de la naturaleza con sus explicaciones causales de las cosas y el principio de universalización de valores y normas morales convierten en fútiles aquellos experimentos. En el modelo habermasiano de ética discursiva, construido sobre la reciprocidad lingüística de la comunicación entre sujetos de una colectividad social, encajan difícilmente vivencias emotivistas de la naturaleza o interacciones dialógicas entre un hipotético sujeto de la naturaleza y actores competentes de un discurso racional. La naturaleza carece de aquello que constituye la quintaesencia del diálogo: la competencia discursiva y la asunción de derechos y deberes en un hipotético consenso. Con tal posición Habermas se mantiene fiel al antropocentrismo kantiano. Conceptos básicos del mismo, tales como la autonomía del sujeto moral, la universalización de normas y el hombre como exclusivo fin en sí mismo son mantenidos, si bien se ven complementados con elementos sociales: consenso, diálogo, comunicación... Ninguno de ellos extrapolable a la naturaleza en calidad de cosujeto competente de una acción comunicativa 40 .

Lamentablemente, pues, la relevancia moral de los problemas medioambientales pasó desapercibida a los moralistas hasta la década de los setenta del siglo XX. Durante un cierto período, incluso, se tuvo al ecologismo como problema vinculado a colectivos marginales, más proclives a la pancarta y a la anomía que adictos al orden y al compromiso. Durante el último cuarto de siglo, sin embargo, se asiste a una explosión de literatura sobre el tema y a la construcción de una conciencia colectiva sobre el problema medioambiental. Mientras amplios sectores juveniles abandonan las utopías revolucionarias para apuntarse al consumismo voraz, surge en otros una forma nueva de conciencia moral, que denuncia los desequilibrios de una civilización técnico-industrial, basada en el expolio de la naturaleza. La ética, en este caso, aspira a poner racionalidad en aquellas percepciones y vivencias de valores que, en relación al problema medioambiental, emergen del mundo de la vida cotidiana 41 .

40 En Erlauterungen zur Diskursethik, Frankfurt a. M., 1991, pp. 220 ss. = Aclaraciones a la ética del discurso. J. Mardomingo (trad.), Madrid, Trotta, 2000, pp. 225 ss., Habermas, dialogando con G. Patzig sobre los deberes respecto a los animales, Oekologische Ethik - innerhalb der Granzen blosser Vernunft, en H. J. Elster (ed.) Umweltschutz - Herasusforderung unserer Generation, Weikersheim, 1984, pp. $67 \mathrm{ss}$. (= existe trad. al castellano: Ética ecológica dentro de los límites de la mera razón, en Hechos, normas, proposiciones, Barcelona, Alfa, 1986, pp. 201-223, se muestra mas receptivo respecto a la ética medioambiental, si bien siempre desde el deontologismo kantiano. Produce una cierta perplejidad a este respecto el peso que Habermas otorga a las experiencias estéticas de la naturaleza. Cf. op. cit., p. 231.

${ }^{41}$ Para una contextualización global del problema véase Ch. Belshaw, Filosofía del medio ambiente. Razón, naturaleza y preocupaciones humanas. I. Gutiérrez y A. Vijande (trads.), Madrid, 2005. Sobre el problema de una ética medioambiental, J. M. ${ }^{a}$ G. ${ }^{a}$ Gómez-Heras (coord.), Ética del medio ambiente. Problema, perspectivas, historia, Madrid, Tecnos, 1997; C. Velayos Castelo, La dimensión moral del ambiente natural. ¿Necesitamos una nueva ética?, Granada, 1996, ofrece también un excelente análisis de la cuestión, manejando una amplia bibliografía. En 


\section{Reconstrucción medioambiental de la racionalidad práctica}

Desde sus prejuicios endémicos la ética tradicional, se dice, estaría incapacitada para convertir al medio natural en materia moral. Y está incapacitada porque su encuadre teórico ha saltado en pedazos bajo presión de la acción tecnológica. La obsolescencia deriva de la nueva dimensión que las consecuencias de la acción humana han adquirido en extensión y duración. La capacidad del hombre para lo bueno y para lo malo se ha incrementado hasta límites insospechados con el instrumental que la ciencia ha posibilitado. El progreso tecnológico y sus aplicaciones al dominio de la naturaleza plantean de modo inesperado nuevas preguntas morales. Para desasosiego de los humanos, el desarrollo tecnológico se acelera y marcha muy por delante del desarrollo moral y jurídico. Lo cual desborda los encuadres de la reflexión moral tradicional, emplazando a ésta ante nuevos retos. De ahí la insistencia con que el ensayismo medioambiental reitera la necesidad de un cambio de modelo ético para tratar los problemas medioambientales. El encuadre tradicional de la ética habría sido desbordado por la nueva problemática de la humanidad bajo la era técnico-industrial: explosión demográfica, migraciones incontrolables, consumismo desbocado, expolio de recursos... El uso de la técnica enfrenta a las decisiones humanas ante alternativas contradictorias en sectores tan cualificados como la planificación de la vida, la explotación de materias primas o la ingeniería genética. Situación que, frente a nostálgicos rousseaunianos o a profetas del catastrofismo, en modo alguno encuentra su solución en la renuncia a la brillante civilización técnico-industrial y en el retorno a la selva o a la caverna. Requiere, por el contrario, una reconstrucción moral de la conducta del hombre con la naturaleza.

Es sabido que contra el modelo de ética medioambiental se han planteado objeciones de peso no liviano. $\mathrm{El}$ antropocentrismo de matriz kantiana recela a este respecto de la ética medioambiental y objeta que se destruyen la autonomía, la libertad y la responsabilidad de los sujetos morales. Éstos, de reconocer un orden objetivo de valores y normas inherentes a la naturale$\mathrm{za}$, verían recortada la espontaneidad de sus acciones y decisiones $\mathrm{y}$, con ello, disminuida su responsabilidad moral. Lo cual sería inevitable en un paradigma ecocéntrico en el que el sujeto moral no sería plenamente autónomo al promulgar los imperativos categóricos, sino que algunos de tales imperativos se encuentran ya dados con antelación en la naturaleza misma. Desde tal posición el deontologismo moral ampliaría la objeción en perspectiva sociológica. En efecto: al entenderse a sí mismo como teoría de normas de comportamiento moral, en las que se codifican imperativos de conciencia

los últimos años han aparecido, además de traducciones de obras importantes, una serie de libros sobre el tema. Me permito recordar los trabajos de Alfredo Marcos, Luciano Espinosa, Joaquín

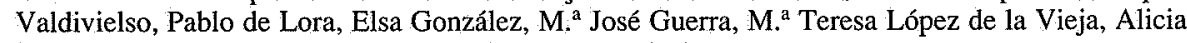
Puleo y la valiosa y abundante producción de Jorge Riechmann. 
y obligaciones, y al carecer la naturaleza de dignidad, valores y exigencias morales, las competencias normativas corresponderían exclusivamente al sujeto humano. Lo cual se prolongaría en una segunda objeción: aquella que procede de la reciprocidad de los deberes y de las obligaciones. Sin tal reciprocidad se carece de base para el concepto de justicia. La puesta en práctica del derecho resultaría imposible, al plantearse conflictos entre partes, una de las cuales carecería de razón para reflexionar, de lenguaje para comunicar, de libertad para decidir y de voluntad para consensuar ${ }^{42}$.

Al existir vínculos sólidos entre la ética medioambiental y la ciencia natural (física, biología, geología, ecología...), los metaéticos reabren inevitablemente un problema de fondo: la famosa falacia naturalista. Como es sabido, la cuestión, formulada por Hume y rehabilitada por Moore, contrapone el ser de la naturaleza y el deber ser moral, concluyendo que del primero no puede hacerse derivar el segundo, dada la diferencia cualitativa existente entre hechos naturales y valores morales. Se diferencian de ese modo dos campos, el de la ética, vinculado a la libertad y a las preferencias axiológicas, y el de la ciencia, constituido por hechos y leyes determinísticas. Una cosa son los hechos que la ciencia describe en secuencia causal y otra los valores que la ética aprecia según lógica de preferencias y libertad. Aquel dualismo habría permitido diferenciar dos tipos de lenguaje: el científico-cognitivo y el ético-valorativo, con lógicas y finalidades heterogéneas. Trasladar la validez del uno al otro implicaría incurrir en falacia. Pero la falacia naturalista, contrargumentan los medioambientalistas, basada en presupuestos antimetafísicos, carecería de racionalidad para amplios sectores del ecologismo, dado que no cabe dudar sobre los valores objetivos de la naturaleza, que instan y apremian a asumir deberes morales. El rechazo por parte del fisiocentrismo de los dualismos valores-hechos, ser-deber, cienciaética, afectaría también, por tanto, a la estructura lógica del discurso moral. Valores naturales como la vida, el equilibrio biótico, la diversidad biológica... asumirían valencia moral e implicarían apremio ético. De ahí que la falacia naturalista, posea solamente validez sobre el supuesto de una naturaleza axiologicamente neutral, tal como la ciencia moderna la percibe al formalizar matemáticamente al cosmos. Si la naturaleza es contemplada desnuda de valores, sobre su desnudez no podrían ciertamente fundamentarse deberes ni obligaciones. Pero no parecen ser ésos los ojos con que el hombre del incipiente siglo XXI contempla al entorno natural ${ }^{43}$.

42 Se ha contraargumentado a este propósito, que aquella reciprocidad tampoco puede ser exigida en los denominados casos marginales, v. gr., el enfermo en estado de coma, el incapacitado mental o el nasciturus, a quienes, sin embargo, les son reconocidos derechos. Trasladada analógicamente la situación a la naturaleza, ¿no podría estar ella representada y defendida también por tutores, apoderados, fedatarios o «defensores de la naturaleza»? Existen ya precedentes de quienes desempeñan tales funciones

${ }^{43}$ Basta echar una ojeada a la fuga de fines de semana desde la ciudad de asfalto a la pradera o a la sombra de una encina para percatarse que la percepción de lo valioso se ha modificado profundamente en las últimas décadas. 
A pesar de las objeciones recordadas, la ética medioambiental programa una expansión importante del mundo moral frente al monopolio del mismo por parte del hombre y la correspondiente ampliación de la normatividad en los Derechos de la naturaleza ${ }^{44}$. Las fronteras fijadas al mundo del deber y de la norma a partir de instancias como la razón, la libertad o el lenguaje dejan de existir en el modelo medioambiental por cuanto un cúmulo de valores, tales como la vida, la finalidad o la belleza y los sentimientos de placerdisplacer, bienestar-malestar, gozo-dolor, al ser fenómenos comunes a los hombres y a los animales, permiten la ampliación del mundo moral más allá de los límites impuestos al mismo por el antropocentrismo. P. Singer ha propuesto el símil de los círculos concéntricos para explicar el modo de expansión de la relevancia moral desde un espacio central polarizado en el hombre y que configuraría el núcleo de la moralidad, hasta espacios extrahumanos: animales, vivientes, plantas..., que si bien no serían computados como agentes, sí desempeñarían el papel de pacientes morales ${ }^{45}$. En correspondencia con tal proceso expansivo de la relevancia moral ha sido propuesta una serie de argumentaciones en pro de la fundamentación de la ética medioambiental de diferente tipo: metafísico, utilitarista, patocentrista, biocentrista, religiosa, fisiocentrista, estética..., dependiendo de los valores inherentes a la naturaleza que se desee resaltar ${ }^{46}$.

Una ética medioambiental sitúa en su centro la categoría de dignidad de la naturaleza ${ }^{47}$. Es sabido que la ética kantiana proclamó al hombre sujeto exclusivo de la dignidad (Würde) e hizo consistir la misma en autonomía y libertad 48 . Sobre ambas construyó el resto de categorías del mundo moral: deber, respeto, eticidad, responsabilidad. La moralidad de una acción «deriva de la idea de dignidad de una esencia racional, que no obedece norma alguna fuera de aquella que ella misma se da». La dignidad es inalienable, no tiene precio, dota de valor intrínseco a los seres, les convierte en acreedores de respeto. A lo que posee dignidad nadie puede acercarse con intención utilitarista por ser fin en sí mismo. Romper los precedentes límites del antro-

\footnotetext{
44 Las normativas sobre derechos de los animales y los ordenamientos referentes a espacios protegidos naturales o conservación de especies muestran que tal hecho se encuentra ya en curso.

45 P. Singer, The expanding Circle. Ethics and Sociobiology, Oxford, 1983, pp. 55 ss. Cf. C. Velayos, La dimensión moral del ambiente natural, pp. 21 ss., 168 ss. y 186 ss.; K. M. MeyerAbich, Vom Baum der Erkenntnis zum Baum des Lebens, Munich, 1997, pp. 65 ss., retomando una idea de Th. Nagel, habla de «esferas concéntricas».

46 Cf. J. M. . G. ${ }^{a}$ Gómez-Heras, «Propuestas de fundamentación de la ética del medio ambiente» en Ética en la frontera, Madrid, Biblioteca Nueva, 2002, pp. 13-46. Una exposición amplia del tema en A. Krebs, Ethics of Nature. A Map, Amsterdam-Atlanta, 1997.

$47 \mathrm{Cf}$. Dignidad de la naturaleza y ética medioambiental, en J. M. ${ }^{\text {a }}$ García Gómez-Heras (coord.), La dignidad de la naturaleza, Granada, Comares, 2000, pp. 1-20.

48 Las precedentes ideas kantianas rezuman nobleza humanista pero también antropocentrismo al referirse exclusivamente al «ser racional» hombre. Cf. Grundlegung zur Metaphysik der Sitten, 2 Abs. = Fundamentación de la metafísica de las costumbres. Ed. bilingüe y trad. de J. Mardomingo, Barcelona, Ariel, 1999, pp. 198-200
} 
pocentrismo kantiano y hacer extensiva la dignidad también a la naturaleza constituye conditio sine qua non de cualquier ética medioambiental que se precie de tal. La dignidad de la naturaleza permite a ésta recuperar las categorías de valor y respeto para la naturaleza. Sobre ellas es posible fundamentar valores intrínsecos y no meramente instrumentales en el medio ambiente. Es más: por analogía con el uso del concepto de dignidad referido al hombre por parte de Kant, serían atribuibles a la naturaleza otros atributos tales como la normatividad o su adscripción al reino de los fines 49 . Que tal atribución sea compatible con el principio de autonomía en tanto soporte de la ética kantiana no parece empresa de fácil realización.

Una ética del medio ambiente se entiende a sí misma como saber racional sobre los valores de la naturaleza y sobre la acción humana que tiene por objeto a los mismos. Trata de establecer racionalmente qué conductas deban ser etiquetadas como buenas o malas, correctas o incorrectas. La razón moral monta guardia no sólo para que los procesos epistemológicos que acompañan a las deliberaciones políticas, económicas o científicas se ajusten a valores morales, sino también para que éstos motiven decisiones arriesgadas, tales como las concernientes a la energía atómica y a los residuos industriales. Sobre los supuestos precedentes la ética medioambiental ha ido construyendo su propio temario y sus propias categorías al hilo del debate. a) ¿Posee la naturaleza valor en sí misma, independientemente del hombre, de modo que a partir de ella pueda fundamentarse un concepto de deber? b) El mundo moral ¿se circunscribe al ámbito de los humanos o es susceptible de ampliación a seres no humanos? c) ¿Requiere la crisis ecológica un nuevo modelo de ética, diferente en sistematización, método y contenidos al vigente en la tradición moral? y todo un elenco de nuevos términos ha ido poblando el panorama del ensayo medioambiental: antropocentrismo, pathocentrismo, fisiocentrismo, biocentrismo, prejuicio de especie, respeto ante la vida, dignidad de la criatura... Ha sido posible, incluso, establecer una tipología de modelos de ética medioambiental 50 .

Entre las propuestas de fundamentación ha adquirido notoriedad la de H. Jonas. Se ha escrito que su Principio de Responsabilidad pretende solucionar un problema de rasgos futuristas con una propuesta filosófica de carácter arcaizante. No todos comparten tal valoración. De hecho, el planteamiento de H. Jonas rezuma sabiduría, aunque ante sus tesis sea pertinente adoptar cautelas. Se parte del hecho de que la acción humana ha experimentado un cambio tan profundo en la civilización técnico-industrial, que la éti-

${ }^{49}$ Cf. J. Nida Rumelin, Von der Würde des Menschen zur Würde der Kreatur en Oekologische Ethik und Rechtstheorie., pp. 359-369; B. Sitter-Liver, «Wurde der Kreatur; Grundlegung, Bedeutung und Funktion eines neuen Verfassungsprinzips», en Ibidem, pp. 355 ss., así como la sólida monografía de H. Baranzke, Würde der Kreatur? Die Idee der Würde im Horizont der Bioethik, Würzburg, 2002, pp. 310-316.

50 Cf. Meyer-Abich, op. cit., pp. 65 ss., establece diferentes tipos de ética medioambiental en orden descendente desde el egocentrismo humano al altruismo fisiocentrista. 
ca tradicional no parece encontrarse en condiciones de asumir los problemas suscitados por la crisis ecológica. Porque la ética tradicional se sustenta sobre tres presupuestos ampliamente invalidados hoy en día: a) que la condición humana está fijada de una vez por todas en una esencia inmutable; b) que el concepto de lo bueno y del valor se hace derivar de la subjetividad del hombre; $c$ ) que las consecuencias de la acción humana son previsibles $\mathrm{y}$, en consecuencia, controlables moralmente. Tales presupuestos, sin embargo, son difícilmente conciliables con los hallazgos de la ciencia contemporánea. Se requiere, por tanto, una reforma sustancial del modelo de ética tradicional y proyectar un modelo moral capaz de digerir los retos lanzados por la crisis medioambiental 51 .

Para finalizar, un par de reflexiones sobre el espacio propio de la ética medioambiental y sobre el estatuto científico-metodológico de la misma, asunto sobre el que habrá que retornar en otra ocasión. De partida: $A$ ) la ética y la ciencia, aun teniendo mucho en común, no son ámbitos homologables. Tampoco la ética medioambiental se identifica con aquellas ciencias afines con las que comparte problemas y fronteras, tales como la biología, la geología, la botánica, la ecología o la zoología. La razón práctica no es reducible a ninguna de ellas. La ética medioambiental es un sector aplicado de la filosofía práctica, como la bioética, aunque algunos la conciban como una perspectiva global desde la que reconstruir todo el mundo moral ${ }^{52}$. Un saber en todo caso, que se ocupa de aquellas decisiones y acciones del hombre, que tienen por objeto la naturaleza, entendida como entorno global de plantas, animales, aires y aguas, que configuran el hábitat humano. Los contenidos de la acción moral, en este caso, permiten diferenciar la ética medioambiental de otras éticas aplicadas o especiales, tales la ética económica o profesional. Pero, sin embargo, comparte con ellas el estatuto científico de una disciplina filosófica o si se prefiere de aquellos saberes que Dilthey etiquetó como Ciencias del espíritu y que hoy llamamos Humanidades. Una ética, en fin, que reivindica un espacio propio en el mundo del deber y rechaza todo intento de reduccionismo por parte de ciencias fronterizas, como la ecología o la biología, cuyas aportaciones para la racionalidad de las decisiones, no obstante, valora en sumo grado. B) Respecto al estatuto científico-

${ }^{51}$ El principio de responsabilidad. Ensayo de una ética para la civilización tecnológica. J. M. ${ }^{\mathrm{a}}$ Fernández (ed.), Barcelona, Herder, 1994. Percibir el trasfondo filosófico desde el que Jonas opera precisa conocer su filosofía de la biología desarrollada en El principio vida. Hacia una biología filosófica, J. Mardomingo (trad.), Madrid, Trotta, 2000. Del pensamiento de H. Jonas me he ocupado en varios ensayos. Cf. J. M. ${ }^{a}$ G. ${ }^{a}$ Gómez-Heras (coord.) La dignidad de la naturaleza. Ensayos sobre ética y filosofía del Medio Ambiente, Granada, Comares, 2000, pp. 93-159, y Tomarse en serio la naturaleza. Ética ambiental en perspectiva multidisciplinar, Madrid, Biblioteca Nueva, 2002, pp. 19-42.

52 Cf. G. Altner, Naturvergessenheit. Grundlagen einer umfassenden Bioethik, Darmstadt, 1991. C. Velayos, Una sola ética para la vida: por una bioética ecológica, en López de la Vieja (ed.), Bioética, entre la medicina y la ética, Salamanca, Universidad, 2005, pp. 83 ss., aboga por recuperar la unidad que tuvieron bioética y ecoética en sus orígenes. 
metodológico de la ética medioambiental, se presupone que comparte las estructuras de la ética en cuanto disciplina filosófica. Ello, no obstante, las peculiaridades del objeto de investigación que trata exigen tratamientos metodológicos muy diferenciados. Mientras que, según cliché convencional, las ciencias de la naturaleza se interesan por la objetividad de los conocimientos y operan según el conocido esquema dualista sujeto-objeto, la ética medioambiental se interesa por los valores, involucrando al sujeto cognoscente y al objeto conocido en la gnoseología y lógica peculiares de los juicios de valor. Como es sabido, en éstos intervienen de forma activa aquellos intereses del conocimiento a que hacen referencia términos como estima, intuición, preferencias, intencionalidad, finalidad, motivación, consecuencias, jerarquización, decisión... y que remiten a la subjetividad o mundo vivido del científico. La elección de un método determinado para el tratamiento de la naturaleza adquiere ella misma dimensión moral y responsabilidades consiguientes. Tales planteamientos exceden con mucho los intereses de la investigación científico-natural, polarizada en la objetividad formalizada. Qué concepto se tenga de la naturaleza determina el método de su tratamiento moral filosófico ${ }^{53}$.

\section{Conclusión: A favor de una ética medioambiental}

En tres conclusiones pudiera ser concretado lo anteriormente escrito en orden a recomponer la racionalidad práctica, integrando en la misma a la ética medioambiental:

1. $\left.{ }^{\mathrm{a}}\right)$ Urgente superación de la dicotomía progreso moral-desarrollo científico-técnico: el desafío ecológico emplaza a nuestra cultura a superar la distancia entre la praxis de la sociedad técnico-industrial y el desarrollo moral. Se constata que los dos modelos fundamentales de éticas de la modernidad, el kantiano y el utilitarista, además de resentirse del prejuicio antropocéntrico, acotan la acción en un espacio y un tiempo abarcables por su proximidad. No menos sensibilidad para lo cercano reflejan los proyectos ético-políticos de Platon o de Aristóteles, cuyo encuadre espacio-temporal es la polis griega. Ambos restan prisioneros de un inmovilismo de las esencias difícilmente conciliable con la evolución como estructura de los seres de la naturaleza. Urge, pues, superar la diacronía asimétrica entre la praxis generalizada en la sociedad industrial y los modelos éticos de que nos servi-

53 Los tipos de concepción de la naturaleza se han incrementado durante las últimas décadas: naturaleza como «autoorganización» E. Jantsh, como «potencia creadora», F. Cramer; como «fulguración», K. Lorenz; como autorrepresentación, A. Portmann; como «expresión de vida de un organismo global», Th. von Uexküll, por no recordar otras cosmologías remotas como las del Timeo de Platón, Estoicos, Escoto Eriúgena, G. Bruno, Spinoza, Goethe, Schelling, Bloch... Cf. Altner, op. cit., pp. 116 ss., y 153 ss. y Lebensbegriffe - der Vergangenheit, der Gegenwart, der Zukunft, en H. W. Ingensiep (hrsg.), Philosophie der natürlichen Mitwelt. Grundlagen, Problema, Perspektiven, Würzburg, 2002, pp. 103 ss. 
mos para cualificar nuestras conductas. Aquella asimetría está causada por acciones cuyas consecuencias se protraen en el tiempo y espacio, traspasando los límites en los que la ética tradicional delimita las consecuencias de la praxis humana. Ésta, en efecto, se centra en interacciones que afectan a la vida personal, a su entorno familiar o a la sociedad de la que se forma parte. En todo caso, un mundo vivido cercanamente en el espacio y en el tiempo. Dentro de los límites de ese mundo el hombre decide y se compromete en cercanía, se ocupa de aquellos valores, intereses y normas del espacio ético próximo. La ética medioambiental requiere, por el contrario, planteamientos y decisiones de largo alcance, exigidos por las consecuencias en el tiempo futuro de las acciones humanas. De ahí que sus presupuestos básicos sean no sólo el hecho de la evolución, sino también la ampliación del horizonte temporal en el que son previsibles las consecuencias de la acción tecnológica.

2. $\left.{ }^{a}\right)$ Complementariedad entre la ética medioambiental y la ética dialógico-social: Existe, sin embargo, y es nuestra opinión, un planteamiento a partir del cual la ética universalista del diálogo social y la ética medioambiental pueden ser consensuadas e, incluso, recíprocamente complementadas 54. Es aquel planteamiento que parte de la convicción de que una sociedad justa solamente es posible con una justicia natural y, a la inversa, una naturaleza equilibrada solamente es posible con la justicia social. Ambas se coimplican. Reconocer múltiples valores de la ética medioambiental implica superar el subjetivismo moral de matriz antropocéntrica para recuperar no solamente valores sociales, sino también valores medioambientales. El sujeto moderno precisa de ser purgado en lo que tiene de individualismo egocéntrico en la relación individuo-sociedad, pero también en lo que tiene de egoísmo utilitarista en la relación hombre-naturaleza. Lo cual presupone, por una parte, reconocer una transubjetividad axiológica inmanente a la naturaleza, que se encuentra a la espera de ser descubierta, valorada y reconocida como buena. Y éste sería el primer paso en el buen camino para descubrir en la naturaleza un componente racional que, por racional, apremia a ser valorado y preferido como tal. La transición desde una transubjetividad axiológica a la secuencia de mecanismos que desembocan en la responsabilidad moral, tanto a nivel individual como colectivo, no debería presentar excesivos obstáculos. Los procesos cognitivos, deliberativos y valorativos, en donde el hombre ejerce como protagonista, a saber: la percepción de valores naturales, la reflexión privada y el debate público, los consensos, los imperativos morales, las decisiones libres e, incluso, la codificación de las mismas en ordenamientos jurídicos democráticos, son etapas de una racionalidad práctica en las que, la previamente reconocida dignidad axiológica de la naturaleza, es complementada con aquellos elementos antropológicos, que siempre han convertido la

\footnotetext{
$54 \mathrm{Cf} . \mathrm{K}$. Ott, Wie ist eine diskursethische Begründung von oekologischen Rechts- und Moralnormen möglich? en J. Nida-Rumelin - D. v. d. Pfordten, Oekologische Ethik und Rechtstheorie, Baden-Baden, 1995, pp. 325-340, y M. Kettner, Ibidem, pp. 301-324.
} 
acción humana en acción moral 55. Por este camino, bloques enteros de la ética medioambiental, englobables en la categoría fenomenológica de mundo de la vida natural, entran a formar parte juntamente con el mundo de la vida social, de una ética no excluyente, en la que se hace justicia al sujeto moderno, a la sociedad contemporánea y a la vida de la naturaleza.

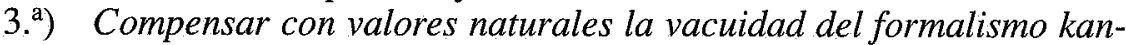
tiano: contra las éticas neokantianas del diálogo y del discurso se ha objetado que mantienen la misma vacuidad formal que aqueja al modelo de Kant. Habermas, sin embargo, en su último período parece sortear con acierto aquella dificultad. Su recurso a la categoría fenomenológica del mundo de la vida le proporciona en este sentido mayores ventajas que el apeliano a priori de la comunidad ideal de comunicación, como lugar de asentamiento y deposito de aquellos valores a los que los participantes en un diálogo discursivo recurren buscando revalidación. El kantismo moral deriva en Habermas, en este caso, hacia una hegeliana Sittlichhkeit, que apunta más allá de la abstracción y soledad del sujeto para recalar en el mundo de valores vivido por la sociedad. Lo cual configuraría, de modo menos unilateral, aquel mundo vivido a tergo al que Habermas remite en calidad de Back Ground sobre el que se asientan las convicciones de los interlocutores del discurso y depósito último de referencia para los propios razonamientos. Lo cual, por otra parte, permite superar con ventaja aquel formalismo típico de las éticas deontológicas de la tradición kantiana, vinculando la universalidad de las normas a la universalidad de unos valores transubjetivos, sean éstos de carácter social o de carácter natural. La racionalidad ilustrada del proyecto kantiano, tan universal como abstracta en su vacuidad de contenidos, resta de ese modo complementada con aquellos elementos expresionistas y precategoriales, tales como vivencias, experiencias, preferencias, etc., que configuran el mundo de la vida personal en una totalidad de sentido. Se trataría de valores tanto de la naturaleza como de la expresividad del sujeto que reivindican estar presentes en la acción comunicativa y ser revalidados por ella a través del discurso. Porque el mundo vivido a tergo, sea como tradición cultural sea como orden normativo o sea como saber social, configura un $a$ priori moral más integral si está sustentado sobre el mundo de la vida natural. Mundo socialmente asumido, que revalidado por la acción comunicativa, reportaría la desactivación de aquellos elementos que provocan las patologías y desequilibrios medioambientales del mundo en el que vivimos. En primer lugar, evitando, mediante la simbiosis entre naturaleza y humanismo, aquellos procesos de colonización y desacoplamiento axiológico que genera una razón técnico-funcional despojada de responsabilidades éticas.

55 Sobre las fases a seguir en el proceso de humanización de la ética medioambiental a partir del descubrimiento de los valores inherentes a la naturaleza, véase J. M. ${ }^{\mathrm{a}}$ G. ${ }^{\mathrm{a}}$ Gómez-Heras (coord.), «Propuestas de fundamentación de la ética del medio ambiente», en Ética en la frontera, Madrid, Biblioteca Nueva, 2002, pp. 17 ss. 